\title{
Early detection of novel Leishmania species DNA in the saliva of two HIV-infected patients
}

\author{
Padet Siriyasatien ${ }^{1,2}$, Sarunyou Chusri ${ }^{3}$, Kanyarat Kraivichian ${ }^{1}$, Narissara Jariyapan ${ }^{4}$, Thanaporn Hortiwakul ${ }^{3}$,
} Khachornsakdi Silpapojakul ${ }^{3}$, Adam M. Pym ${ }^{5}$ and Atchara Phumee ${ }^{1 *}$ (D)

\begin{abstract}
Background: Leishmaniasis caused by two new species of Leishmania; L. siamensis and L. martiniquensis have been recently described in Thailand. The disease has mainly been documented in AIDS patients from southern Thailand. In this study, polymerase chain reaction (PCR) was used to determine HIV-Leishmania co-infection in southern Thailand.

Methods: One $\mathrm{ml}$ of saliva and $3 \mathrm{ml}$ of EDTA blood were collected from HIV-infected patients for PCR detection of Leishmania DNA, cloning and sequencing. The positive PCR samples were then cultured on Schneider's insect medium.

Results: Three out of 316 saliva samples collected from HIV-infected patients were found to be positive for Leishmania DNA (0.95\%). Among the positive samples, one patient was observed with disseminated cutaneous lesions and also tested positive via saliva, whole blood and buffy coat in PCR. The second case presenting with nodular lesions also gave a positive saliva test via PCR two months prior to buffy coat. This diagnosis was confirmed by microscopic examination and a culture of biopsy samples from a nodule. The last case was an asymptomatic Leishmania infection which tested PCR positive only in saliva with a consecutive sample collection conducted for three months.

Conclusions: The prevalence of Leishmania infection in HIV infected patients within this study is $0.95 \%$. Leishmania DNA was detected in saliva by PCR prior to blood and buffy coat of two HIV infected patients. Early detection of Leishmania DNA in saliva would be beneficial for the follow up of asymptomatic Leishmania infected patients, the early treatment of leishmaniasis and for surveillance survey purpose. However, full evaluation of sensitivity and specificity of this technique with a large cohort of patients is required before deployment.
\end{abstract}

Keywords: Leishmania, Saliva, HIV-infection, PCR

\section{Background}

Autochthonous leishmaniasis cases in Thailand have been increasingly diagnosed in recent years. The disease was described in both immunocompetent and immunocompromised patients, such as those with AIDS [1] and in systemic steroid therapy [2]. Approximately 20 cases of autochthonous leishmaniasis have now been documented, with most found in the south of Thailand [1-9]. Sukmee and others first reported a suspected

\footnotetext{
* Correspondence: amphumee@gmail.com

${ }^{1}$ Department of Parasitology, Faculty of Medicine, Chulalongkorn University, Bangkok 10330, Thailand

Full list of author information is available at the end of the article
}

new Leishmania species from Thailand (2008) [3] which was named L. siamensis [7]. A report by Leelayoova et al. (2013) [10] demonstrated that L. siamensis in Thailand has two lineages: the PG lineage or PCM1 isolate (Accession no JX195640) [3] and TR lineage or PCM2 isolate (Accession no EF200012) [7]. However, more recently Pothirat et al. (2014) [11] identified a PCM1 and a new isolate from northern Thailand LSCM1 (Accession no JX898938) which are L. martiniquensis as described by Desbois et al. (2014) [12], and only the PCM2 isolate was identified as L. siamensis. They also reiterated that most cases of leishmaniasis are caused by L. martiniquensis in Thailand. More recently, Chiewchanvit et al. (2015) also 
described a case of HIV and L. martiniquensis co-infection in northern Thailand who presented with chronic generalized fibrotic skin lesions [13].

In other parts of the world such as isolates from Myanmar patients (Accession no KF211417) [2], cows in Switzerland (Accession no GQ281282), a horse in Germany (Accession no GQ281278) and a horse in the USA (Accession no JQ617283) [14-16] may be L. martiniquensis. Liautaud et al. (2015) reported the first case of visceral leishmaniasis caused by L. martiniquensis from the Caribbean [17]. This indicates that L. martiniquensis has a worldwide distribution while $L$. siamensis is limited in its geographic distribution.

Three clinical forms of these novel Leishmania species have been described: visceral, disseminated cutaneous, and combined disseminated cutaneous with visceral [1-9, 11, 13]. The disease has been described mostly in immunocompromised patients, especially those with AIDS. Apart from L. martiniquensis and L. siamensis, an autochthonous leishmaniasis case caused by $L$. infantum was also reported from Thailand [18].

The prevalence of leishmaniasis in Thailand has never been fully studied. Screening tests for leishmaniasis, such as Enzyme-linked immunosorbent assay (ELISA), Direct antiglobulin test (DAT) and rK39 dipsticks, are not generally available. Microscopic examination and culture are time-consuming and require expertise to be reliable. Microscopy, culture and PCR are generally the methods of choice used for diagnosis [1].

PCR has been developed to detect Leishmania DNA, and Leishmania species were identified by a sequence analysis [19-21]. PCR has high sensitivity and specificity for detecting Leishmania DNA [22, 23] and has been used for detection from various clinical samples including blood, bone marrow, tissue, saliva, and urine [1-6]. Saliva has been shown to be a good source for the detection of the new Leishmania species DNA [1-6].

Several previous studies demonstrated that Leishmania DNA and antibodies were present in oral secretions and saliva, such as L. braziliensis DNA from Brazil [24],
L. donovani from China [25] and L. infantum from Tunisia [26]. In Thailand, Phumee et al. (2013) demonstrated that saliva is a good source for PCR detection of novel Leishmania species DNA in Thailand [1, 2, 4-6, 9]. They also showed that the Leishmania DNA levels in saliva decreased after treatment [1]. Saliva could be used as a biomarker to detect the new Leishmania species infection. Furthermore, the collection of saliva is non-invasive, requires no special equipment, and is suitable for children and elders [27, 28].

The prevalence of the disease in Thailand has never been fully investigated. This study's objectives are to determine the prevalence of Leishmania infection in HIVinfected Thai patients from southern Thailand through PCR analysis of saliva and blood samples.

\section{Methods}

Study design

The study was conducted in southern Thailand from June to September 2013. A total of 316 HIV-infected patients who came for HIV treatment were enrolled in the study at the Division of Infectious Diseases of Faculty of Medicine, Prince of Songkla University. One $\mathrm{ml}$ of saliva and $3 \mathrm{ml}$ of EDTA blood were collected for PCR detection of Leishmania DNA.

\section{Ethics approval}

Informed consent was obtained from all subjects according to protocols approved by the Institutional Review Board on Human Research of the Faculty of Medicine, Chulalongkorn University (COA No. 768/2012).

\section{Study population}

Blood and saliva samples were collected from HIV-infected patients who resided in southern Thailand. A total of 316 HIV-infected patients involved in treatment at the Division of Infectious Diseases were enrolled in the study.

\section{DNA extraction}

One ml of whole saliva was used to extract DNA from the tissue using the Invisorb ${ }^{\circ}$ Spin Tissue Mini Kit (STRATEC

Table 1 Clinical presentations, CD4+ T cell levels, PCR, and Culture/Tissue biopsy for Leishmania parasite ${ }^{a}$

\begin{tabular}{|c|c|c|c|c|c|c|c|c|c|c|c|c|}
\hline \multirow[t]{3}{*}{ Patient } & \multirow[t]{3}{*}{ Clinical Presentation } & \multirow{3}{*}{$\begin{array}{l}\text { CD4+ T } \\
\text { cell count } \\
\left.\text { (cells/mm } \text { mm }^{3}\right)\end{array}$} & \multicolumn{9}{|c|}{ Results of PCR for Leishmania } & \multirow{3}{*}{$\begin{array}{l}\text { Culture/Tissue biopsy } \\
\text { for Leishmania }\end{array}$} \\
\hline & & & \multicolumn{3}{|c|}{$\begin{array}{l}\text { First sample } \\
\text { collection }\end{array}$} & \multicolumn{3}{|c|}{$\begin{array}{l}\text { Second sample } \\
\text { collection }\end{array}$} & \multicolumn{3}{|c|}{$\begin{array}{l}\text { Third sample } \\
\text { collection }\end{array}$} & \\
\hline & & & $S$ & B & $\mathrm{BF}$ & $\mathrm{S}$ & B & $\mathrm{BF}$ & $S$ & B & $\mathrm{BF}$ & \\
\hline 32 year old & Relapse disseminated $C L 2$ years after treatment & 110 & + & + & + & & colle & & & coll & cted & $+/+$ \\
\hline \multicolumn{13}{|l|}{ Male } \\
\hline 48 year old & \multirow{2}{*}{$\begin{array}{l}\text { Nodular } \mathrm{CL} \text {, relapse } 2 \text { years after treatment for } \\
\text { disseminated } \mathrm{CL}\end{array}$} & \multirow[t]{2}{*}{207} & \multirow[t]{2}{*}{+} & \multirow[t]{2}{*}{-} & \multirow[t]{2}{*}{-} & \multirow[t]{2}{*}{+} & \multirow[t]{2}{*}{-} & \multirow[t]{2}{*}{-} & \multirow[t]{2}{*}{+} & \multirow[t]{2}{*}{-} & \multirow[t]{2}{*}{+} & \multirow[t]{2}{*}{$+/+$} \\
\hline Male & & & & & & & & & & & & \\
\hline 28 year old & \multirow[t]{2}{*}{ Asymptomatic } & \multirow[t]{2}{*}{617} & \multirow[t]{2}{*}{+} & \multirow[t]{2}{*}{-} & \multirow[t]{2}{*}{-} & \multirow[t]{2}{*}{+} & \multirow[t]{2}{*}{-} & \multirow[t]{2}{*}{-} & \multirow[t]{2}{*}{+} & \multirow[t]{2}{*}{-} & \multirow[t]{2}{*}{-} & \multirow[t]{2}{*}{$-/ N / A$} \\
\hline Female & & & & & & & & & & & & \\
\hline
\end{tabular}

${ }^{a} S$ Saliva; B Blood; BF Buffy coat; +: positive; -: Negative; N/A: not available; CL: Cutaneous leishmaniasis 
Molecular GmbH, Germany) according to the manufacturer's instructions. To extract the DNA, $200 \mu$ of EDTA blood and $50 \mu \mathrm{l}$ of buffy coat were used with the extraction kit, Invisorb ${ }^{\circ}$ Spin blood Mini Kit (STRATEC Molecular $\mathrm{GmbH}$, Germany). Extracted DNA was eluted in $50 \mu \mathrm{l}$ of elution buffer. The quantity and quality of the extracted DNA were determined using a Nanodrop 2000c (Thermo Scientific, Singapore). Extracted DNA samples were kept at $-80{ }^{\circ} \mathrm{C}$ for long-term storage.

\section{PCR amplification}

Amplification was performed in a PCR Mastercycler pro (Eppendorf, Germany) with conditions as follows; denaturation at $94{ }^{\circ} \mathrm{C}$ for $4 \mathrm{~min}$, followed by 40 cycles of $94{ }^{\circ} \mathrm{C}$ for $1 \mathrm{~min}$; $65^{\circ} \mathrm{C}$ for $1 \mathrm{~min}$; and $72{ }^{\circ} \mathrm{C}$ for $1 \mathrm{~min}$, with the final extension at $72{ }^{\circ} \mathrm{C}$ for $7 \mathrm{~min}$. The forward and reverse ITS1 regions of the rRNA of Leishmania parasite primers were LeF: 5' TCC GCC CGA AAG TTC ACC GAT A 3' and LeR: 5' CCA AGT CAT CCA TCG CGA CAC G 3', respectively [29]. In order to maintain that the template DNA had been extracted properly, primers that anneal to human DNA (UNFOR403: 5'-TGA GGA CAA ATA TCA TTC TGA GG-3' and UNREV1025: 5'-GGT TGT CCT CCA ATT CAT GTT A-3') were used [30]. Therefore, clinical samples which contain human DNA should show the PCR products of $628 \mathrm{bps}$. The products were analyzed on $1.5 \%$ agarose gel electrophoresis, stained with $0.5 \mu \mathrm{g} / \mathrm{ml}$ ethidium bromide and visualized with Quantity One quantification analysis software, version 4.5.2 Gel Doc EQ system (Bio-Rad, USA). DNA from cultured Leishmania promastigotes isolated from a patient [5] was used as the positive control. DNA from saliva and EDTA blood from a healthy individual who had never traveled into endemic areas were used as negative controls.

\section{Cloning, sequencing and nucleotide analysis}

The study was designed to use cloning for sequencing rather than direct sequencing because the ITS1 primers used in this study can amplify closely L. martiniquensis and L. siamensis at 379 and 371 bps, respectively. Moreover, PCR products obtained from some reactions contained small amount of DNA, while direct sequencing requires at least 30-50 ng/ $\mu \mathrm{l}$ of DNA. Amplified PCR products were ligated into pGEM-T Easy Vector (Promega, USA). The ligated vectors were transformed into DH5 $\alpha$ competent cells and screened through the bluewhite colony selection system. The suspected positive colonies were cultured for further plasmid DNA extraction using the Invisorb ${ }^{\circ}$ Spin Plasmid Mini kit (STRATEC Molecular $\mathrm{GmbH}$, Germany), following the manufacturer's instructions. Purification was performed according to the $1^{\text {st }}$ BASE DNA sequencing system $\left(1^{\text {st }}\right.$ base laboratories, Malaysia) using universal forward T7 primer. Nucleotide sequences were analyzed using the BioEdit Sequence Alignment Editor Version 7.0.9.0. The consensus sequences were compared with available sequence data in GenBank using BLAST search (available at http:// blast.ncbi.nlm.nih.gov/Blast.cgi). Sequences obtained from this study were submitted to GenBank to be assigned accession numbers.

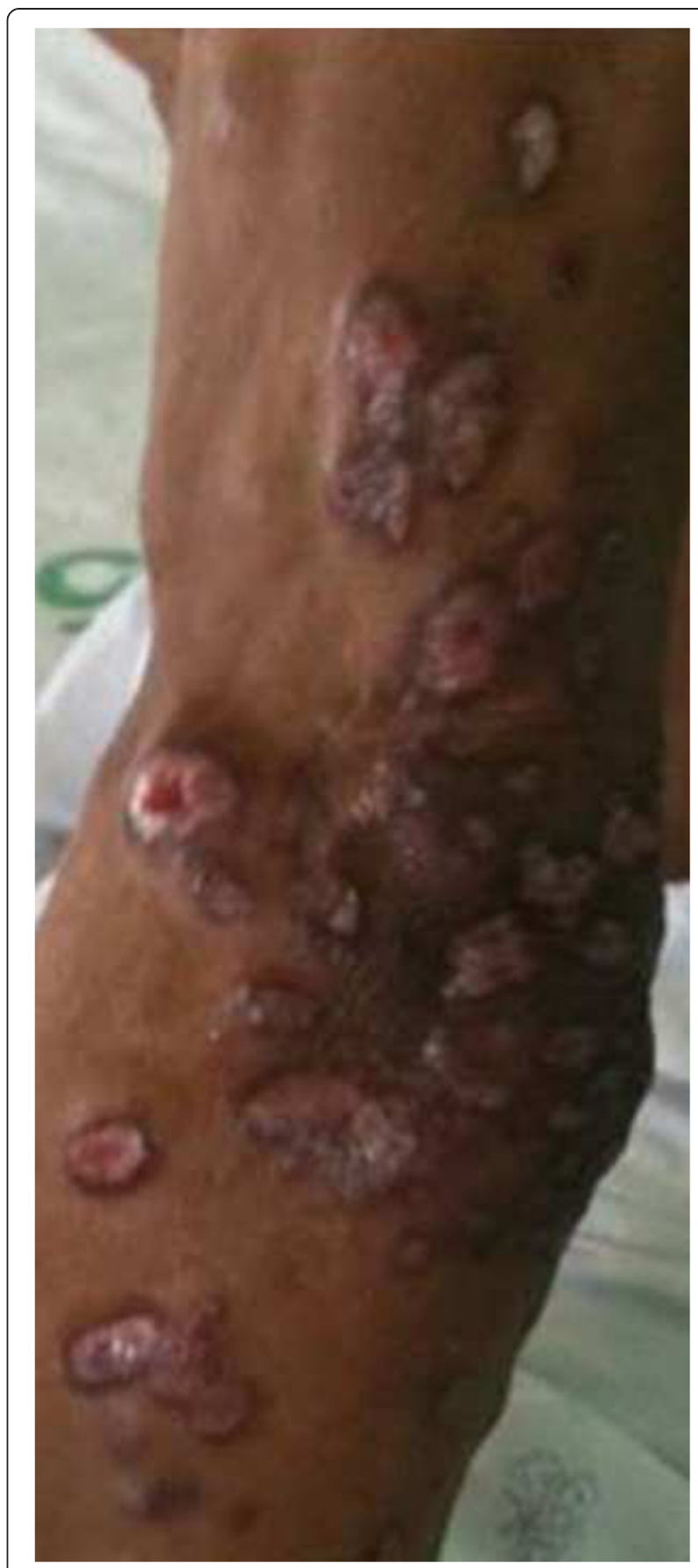

Fig. 1 Cutaneous leishmaniasis lesions of the patient 1 


\section{Phylogenetic tree construction}

A phylogenetic tree was constructed by Maximum-likelihood method using the Kimura's 2-parameter model implemented in MEGA6 version 6.06 and the tree was tested using 1000 bootstrap replicates. ITS1 sequences of confirmed L. martiniquensis (KM677931) [10] and L. siamensis (JX195640) [9] were used to compared with ITS1 sequences of our study. Bodo caudatus accession no. AY028450 was used as an outgroup.

\section{Culture of Leishmania parasite}

Positive PCR samples were cultured on Schneider's insect medium (Sigma-Aldrich, USA), which contained $10 \%$ fetal bovine serum, $100 \mathrm{U} / \mathrm{ml}$ of penicillin, and $100 \mu \mathrm{g} / \mathrm{ml}$ of streptomycin (Sigma-Aldrich, USA). The samples were then incubated at $25 \pm 2{ }^{\circ} \mathrm{C}$. The promastigotes were observed daily under an inverted microscopy (Olympus, Japan).

\section{Tissue biopsy and staining}

A tissue biopsy was performed on an ulcer or nodule from the PCR-positive study patients. Tissue sections were stained with Hematoxylin and Eosin (H\&E) and examined under a light microscope (Olympus, Japan) at 100X magnification.

\section{Results}

Saliva and blood samples were tested with Leishmaniaspecific primers, ITS1 gene by PCR. Three of the 316 saliva samples were positive for Leishmania species DNA $(0.95 \%)$. Among these three positive cases, two had been diagnosed as leishmaniasis two years previously (Table 1). The first of these cases, involving a 32-year-old male, was diagnosed for disseminated CL 2 years previously. He was treated with amphotericin B deoxycholate and itraconazole, following which his lesions regressed and all samples tested by PCR were negative for Leishmania [1-6]. However, in June 2013, he developed multiple papules and ulcers (Fig. 1). A CD4+ T-cell count revealed 110 cells $/ \mathrm{mm}^{3}$ and he was started on tenofovir, lamivudine and nevirapine for treatment of HIV. Saliva, whole blood, buffy coats, and tissue biopsy were also positive for Leishmania DNA. Both culture and $H \& E$ stains confirmed the recurrent diagnosis by showing Leishmania in a skin biopsy (Table 1).

Two other cases were positive only in saliva from the first PCR sample collected (Table 1). One of these cases was a 48-year-old male who was diagnosed two years previously with disseminated leishmaniasis [5] and was treated with liposomal amphotericin B, followed by itraconazole. His clinical status improved and blood and saliva samples were negative after treatment. He received boosted lopinavir and lamivudine for HIV. Blood and saliva samples were collected for a Leishmania PCR in July 2013 with only saliva testing positive (Table 1 and Fig. 2a). He developed nodules on his brow, left second toe, left ring finger, and left elbow. His lesions were described by Phumee et al. (2014) [9]. Blood and saliva samples were then collected for two consecutive months (August and September 2013). PCR was positive in buffy coat and saliva samples two months after the first collection (September 2013), (Table 1 and Fig. 2a). A tissue biopsy was performed at a nodule from his brow in September 2013. A PCR of the biopsy sample was positive for the novel Leishmania species. (Table 1 and Fig. 2a). The first and second cases of leishmaniasis relapsed approximately 2 years after the treatment [5].

The last case was a 28-year-old female who was asymptomatic but whose PCR was positive in saliva (July 2013) and had a CD4+ T-cell count of 617 cells $/ \mathrm{mm}^{3}$.

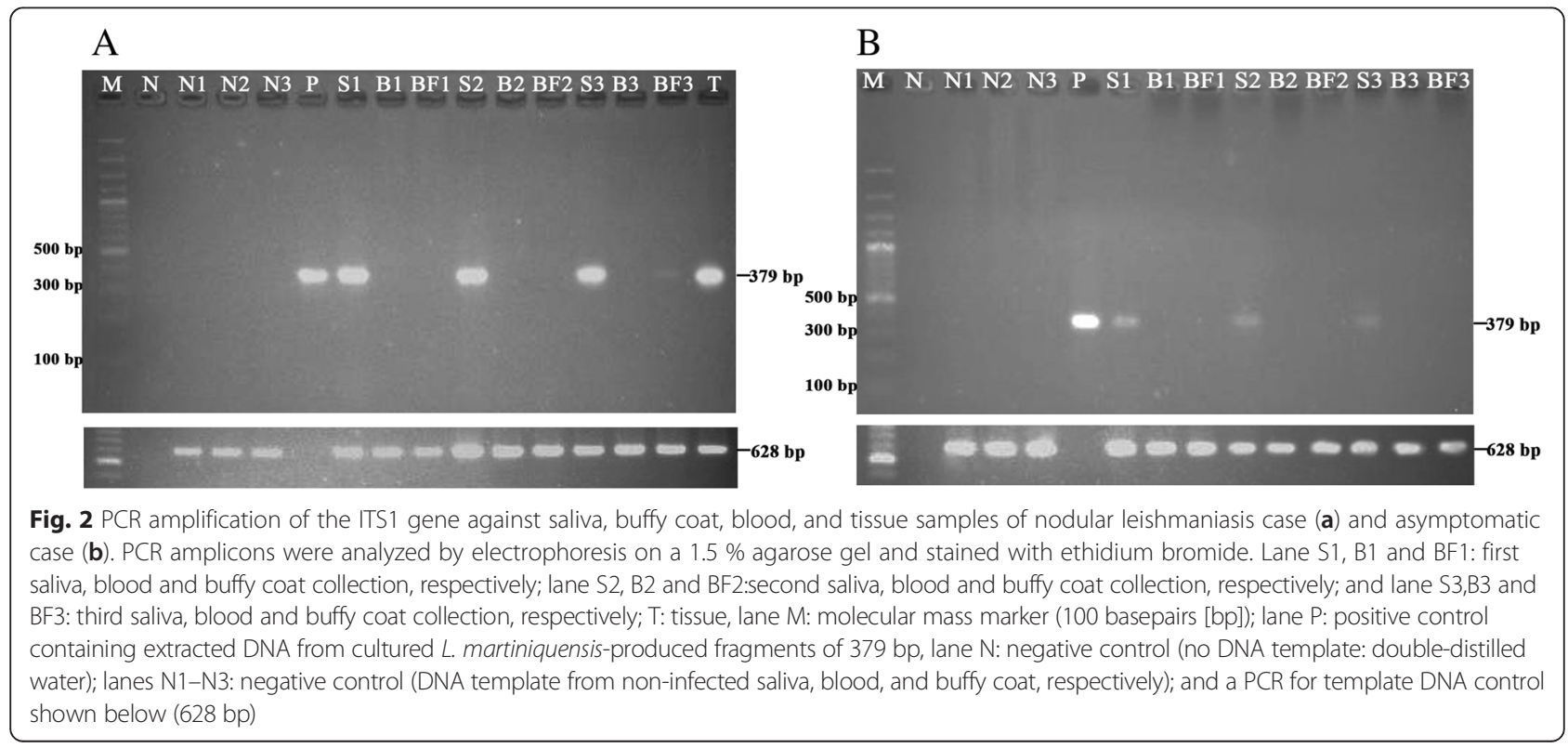


She did not receive any treatment for HIV. Blood and saliva collected for two consecutive months (August and September 2013) were negative, but PCR remained positive (Table 1 and Fig. 2b).

Amplified sequences obtained from saliva, blood, buffy coat, and tissue of the patient 1 were assigned for accession numbers KU050856-KU050859 respectively. Amplified sequences obtained from saliva, buffy coat, and tissue of patient 2 were assigned for accession numbers KU050860KU050862, while the amplified sequence from saliva of patient 3 was assigned accession number of KU050863.
The nucleotide sequencing of all PCR-positive samples were $100 \%$ identical to L. martiniquensis (Fig. 3a and b). The UNFOR403 and UNREV1025 primers which were annealed specifically to human DNA gave positive results for all clinical samples (Fig. 2a and b). This showed that all extracted DNA from clinical samples were extracted properly.

\section{Discussion}

This study identified Leishmania co-infections in HIV patients using saliva and blood samples for PCR within
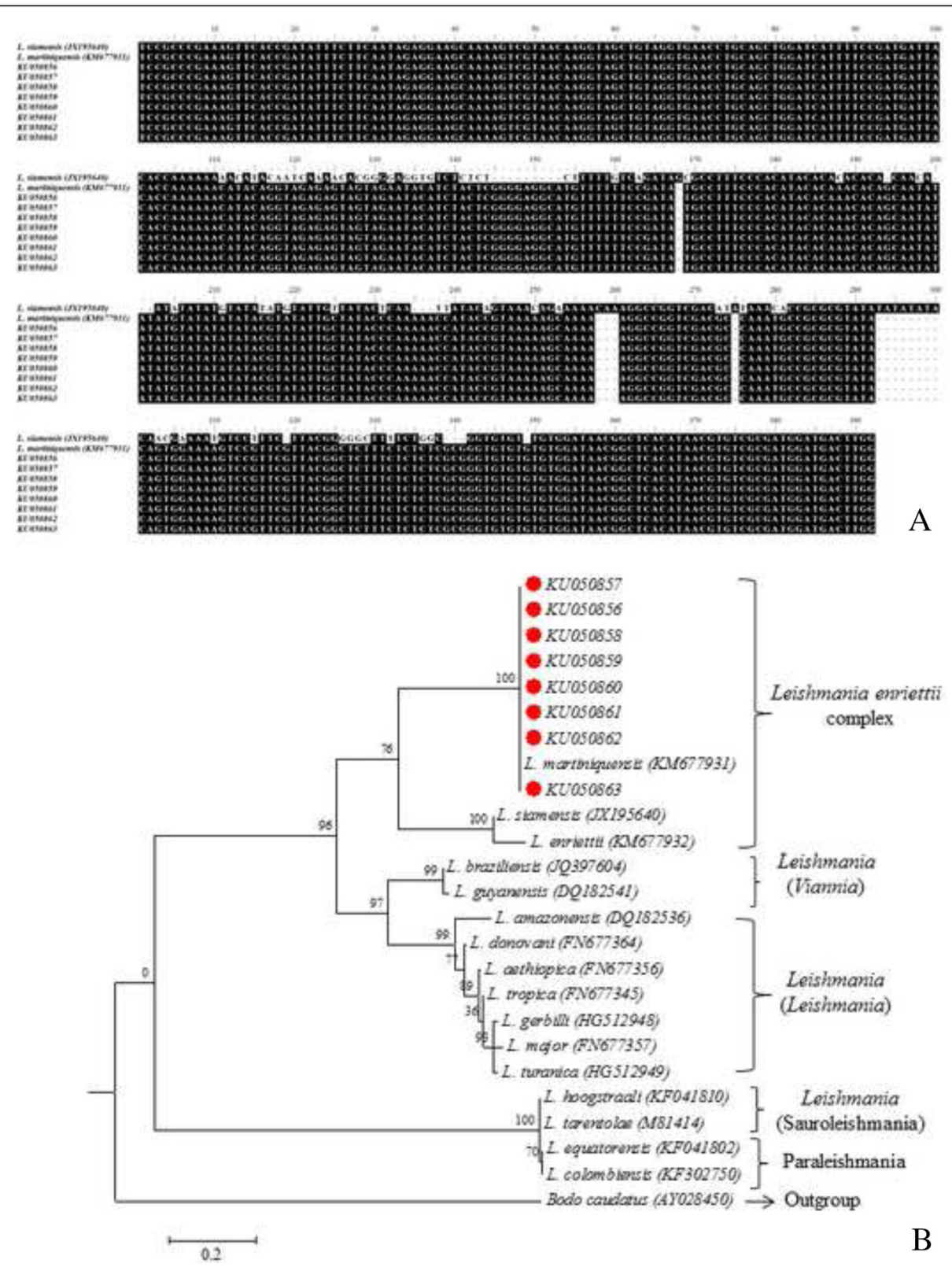

Fig. 3 Sequence comparison between L. martiniquensis and L. siamensis, the different in size and sequences were observed. Red circle indicated $L$. martiniquensis obtained from this study (a). A phylogenetic tree showed that both $L$. martiniquensis and $L$. siamensis were classified into $L$. enriettii complex and were discriminate to other Leishmania species (b) 
an endemic area of Thailand. Three out of 316 saliva samples were positive for PCR Prevalence of Leishmania infection in HIV infected patients of this study was $0.95 \%$. In 2012, Orsini and others investigated prevalence of Leishmania infection among 381 HIV-infected patients who living in endemic areas of Brazil. The results showed positive for Leishmania in blood samples by using PCR targeted to kDNA region, ELISA, Indirect fluorescent antibody test (IFAT), and rK39 at $6.3 \%$, $10.8 \%, 3.9 \%, 0.8 \%$ [30] respectively. Comparing the PCR results, the prevalence of Leishmania infection in HIV patients of our study is lower than the result reported by Orsini et al. (2012) [31].

Interestingly in this study, Leishmania DNA was detected in saliva prior to appearing in buffy coat in patient two and was also detected only in saliva for patient three. A definite diagnosis was confirmed using microscopy and a culture of tissue biopsy from a nodular lesion. Sequence analysis of amplified PCR products were $100 \%$ identical to L. martiniquensis (Accession no KM677931).

Sequence analysis demonstrated that the amplified ITS1 gene region in this study was able to discriminate between L. martiniquensis and L. siamensis (Fig. 3a). Phylogenetic tree construction showed that both L. martiniquensis and $L$. siamensis were classified into the $L$. enriettii complex (Fig. 3b), a result that is similar to that previously reported by Pothirat et al. (2014) [11]. Again, similar to the result of Pothirat et al. (2014) [11] which mentioned that most cases of leishmaniasis in Thailand are caused by L. martiniquensis, all three cases of this study were also infected by L. martiniquensis.

Patients infected with leishmaniasis in Thailand often have diffuse cutaneous [7, 9], visceral leishmaniasis [1,3-8] or overlapping diffuse cutaneous and visceral forms [1, 5-9]. Two leishmaniasis cases of this study were presented with cutaneous lesion, one case had diffuse cutaneous lesion (Fig. 1) while another presented with multiple nodular lesions [9].

This study also demonstrated the first asymptomatic $L$. martiniquensis infection in Thailand. Clinical samples were consecutively collected for two months. Leishmania DNA was still detected only in the saliva of the asymptomatic case. A study by Phumee et al. (2013) previously demonstrated that Leishmania DNA was detected in saliva and buffy coat in all of their cases [1]. However, in this study we found that it was detected only in saliva two months prior to buffy coat, in a patient presenting with nodular leishmaniasis. More recently, Sriworarat et al. (2015) also demonstrated that L. martiniquensis DNA was present in saliva prior to blood sample via the use of loop mediated isothermal amplification (LAMP) technique [32]. In this study, Leishmania DNA was also detected only in the saliva of an asymptomatic patient. HIV and leishmaniasis co-infection has been previously reported from Thailand [1, 3-9]. Most of these cases were diagnosed from bone marrow or tissue biopsies, and some cases died soon after without therapy $[1,7]$.

\section{Conclusions}

Our findings showed that early detection of Leishmania DNA was found when conducting a PCR from the saliva of two HIV infected patients. This could result in the closer follow up of asymptomatic infected patients and lead to earlier treatment of symptomatic leishmaniasis which could decrease morbidity and mortality rates. This could aid the development of disease surveillance tools, especially in asymptomatic cases therefore improving the design of control strategies. However, before the technique can be deployed, sensitivity and specificity of the test should be evaluated with the larger number of patients.

\section{Competing interests}

The authors have declared that no competing interests exist.

\section{Authors' contributions}

Sample collected data for the experiment: SC, TH, KS. Designed the experiments and wrote the paper: AP, PS, AMP. Involved in the discussions and data analysis: AP, PS, KK, NJ. All authors read and approved the final manuscript.

\section{Acknowledgments}

This study was supported by the Thailand Research Fund and Chulalongkorn University (RSA 5780024), Rachadapisek Sompote Fund for Postdoctoral Fellowship, Chulalongkorn University, National Science and Technology Development Agency (Thailand), P-12-01458 and Research Chair Grant.

\section{Author details}

'Department of Parasitology, Faculty of Medicine, Chulalongkorn University, Bangkok 10330, Thailand. ${ }^{2}$ Excellence Center for Emerging Infectious Disease, King Chulalongkorn Memorial Hospital, Thai Red Cross Society, Bangkok 10330, Thailand. ${ }^{3}$ Division of Infectious Diseases, Department of Internal Medicine, Faculty of Medicine, Prince of Songkla University, Songkhla 90110, Thailand. ${ }^{4}$ Department of Parasitology, Faculty of Medicine, Chiang Mai University, Chiang Mai 50200, Thailand. ${ }^{5}$ School of Life Sciences, University of Liverpool, Liverpool, UK.

Received: 1 September 2015 Accepted: 15 February 2016

Published online: 24 February 2016

\section{References}

1. Phumee A, Kraivichian K, Chusri S, Noppakun N, Vibhagool A, Sanprasert V, et al. Detection of Leishmania siamensis DNA in saliva by polymerase chain reaction. Am J Trop Med Hyg. 2013;89:899-905.

2. Noppakun N, Kraivichian K, Siriyasatien P. Disseminated dermal leishmaniasis caused by Leishmania siamensis in a systemic steroid therapy patient. Am J Trop Med Hyg. 2014;91:869-70.

3. Sukmee T, Siripattanapipong S, Mungthin M, Worapong J, Rangsin R, Samung $Y$, et al. A suspected new species of Leishmania, the causative agent of visceral leishmaniasis in a Thai patient. Int J Parasitol. 2008;38:617-22.

4. Suankratay C, Suwanpimolkul G, Wilde H, Siriyasatien P. Case Report: autochthonous visceral leishmaniasis in a human immunodeficiency virus (HIV)-infected patient: the first in Thailand and review of the literature. Am J Trop Med Hyg. 2010;82:4-8.

5. Chusri S, Hortiwakul T, Silpapojakul K, Siriyasatien P. Case Report: consecutive cutaneous and visceral leishmaniasis manifestations involving a novel Leishmania species in two HIV patients in Thailand. Am J Trop Med Hyg. 2012;87:76-80.

6. Jungudomjaroen S, Phumee A, Chusri S, Kraivichian K, Jariyapan N, Payungporn $\mathrm{S}$, et al. Detection of Leishmania martiniquensis DNA in various clinical samples by quantitative PCR. Trop Biomed. 2015;32(4):736-44. 
7. Bualert L, Charungkiattikul W, Thongsuksai P, Mungthin M, Siripattanapipong S, Khositnithikul R, et al. Case Report: autochthonous disseminated dermal and visceral leishmaniasis in an AIDS patient, southern Thailand, caused by Leishmania siamensis. Am J Trop Med Hyg. 2012;86:821-4.

8. Osatakul S, Mungthin M, Siripattanapipong S, Hitakarun A, Kositnitikul R, Naaglor $T$, et al. Recurrences of visceral leishmaniasis caused by Leishmania siamensis after treatment with amphotericin B in a seronegative child. Am J Trop Med Hyg. 2014;90:40-2.

9. Phumee A, Chusri S, Kraivichian K, Wititsuwannakul J, Hortiwakul T, Thavara U, et al. Multiple Cutaneous Nodules in an HIV-Infected Patient. PLoS Negl Trop Dis. 2014;8(12):e3291.

10. Leelayoova S, Siripattanapipong S, Hitakarun A, Kato H, Tan-ariya P, Siriyasatien $P$, et al. Multilocus characterization and phylogenetic analysis of Leishmania siamensis isolated from autochthonous visceral leishmaniasis cases, southern Thailand. BMC Microbiol. 2013;13:60.

11. Pothirat T, Tantiworawit A, Chaiwarith R, Jariyapan N, Wannasan A, Siriyasatien $P$, et al. First isolation of Leishmania from Northern Thailand: case report, identification as Leishmania martiniquensis and phylogenetic position within the Leishmania enriettii complex. PLoS Negl Trop Dis. 2014;8(12):e3339.

12. Desbois N, Pratlong F, Quist D, Dedet JP. Leishmania (Leishmania) martiniquensis n. sp. (Kinetoplastida: Trypanosomatidae), description of the parasite responsible for cutaneous leishmaniasis in Martinique Island (French West Indies). Parasite. 2014;21:12.

13. Chiewchanvit S, Tovanabutra N, Jariyapan N, Bates MD, Mahanupab P, Chuamanochan M, Tantiworawit A, Bates PA, 2015. Chronic generalized fibrotic skin lesions from disseminated leishmaniasis caused by Leishmania martiniquensis in two HIV-infected patients from northern Thailand. Br J Dermatol. doi: 10.1111/bjd.13812

14. Muller N, Welle M, Lobsiger L, Stoffel MH, Boghenbor KK, Hilbe M, et al. Occurrence of Leishmania sp. in cutaneous lesions of horses in Central Europe. Vet Parasitol. 2009;166(3-4):346-51.

15. Lobsiger L, Muller N, Schweizer T, Frey CF, Wiederkehr D, Zumkehr B, et al. An autochthonous case of cutaneous bovine leishmaniasis in Switzerland. Vet Parasitol. 2010:169(3-4):408-14.

16. Reuss SM, Dunbar MD, Calderwood Mays MB, Owen JL, Mallicote MF, Archer $L L$, et al. Autochthonous Leishmania siamensis in horse, Florida, USA. Emerg Infect Dis. 2012;18(9):1545-7.

17. Liautaud B, Vignier N, Miossec C, Plumelle Y, Kone M, Delta D, et al. First case of visceral leishmaniasis caused by Leishmania martiniquensis. Am J Trop Med Hyg. 2015;92(2):317-9.

18. Maharom P, Siripattanapipong S, Mungthin M, Naaglor T, Sukkawee R, Pudkorn $\mathrm{R}$, et al. Visceral leishmaniasis caused by Leishmania infantum in Thailand. Southeast Asian J Trop Med Public Health. 2008;39:988-90.

19. Schönian G, Nasereddin A, Dinse N, Schweynoch C, Schallig HD, Presber W, et al. PCR diagnosis and characterization of Leishmania in local and imported clinical samples. Diagn Microbiol Infect Dis. 2003;47:349-58.

20. Lemrani M, Hamdi S, Laamrani A, Hassar M. PCR detection of Leishmania in skin biopsies. J Infect Developing Countries. 2009;3:115-22.

21. Osman OF, Oskam L, Zijlstra EE, Kroon NC, Schoone GJ, Khalil ET, et al. Evaluation of PCR for diagnosis of visceral leishmaniasis. J Clin Microbiol. 1997;35:2454-57.

22. Marques MJ, Volpini AC, Machado-Coelho GL, Machado-Pinto J, da Costa CA, Mayrink W, et al. Comparison of polymerase chain reaction with other laboratory methods for the diagnosis of American cutaneous leishmaniasis: diagnosis of cutaneous leishmaniasis by polymerase chain reaction. Diagn Microbiol Infect Dis. 2006;54:37-43.

23. Al-Jawabreh A, Schoenian G, Hamarsheh O, Presber W. Clinical diagnosis of cutaneous leishmaniasis: a comparison study between standardized graded direct microscopy and ITS-PCR of giemsa-stained smears. Acta Trop. 2006;99:55-61.

24. Corvalan FH, Sampaio RN, Brustoloni YM, Andreotti R, Lima Ju' nior MS. DNA identification of Leishmania (Viannia) braziliensis in human saliva from a patient with American cutaneous leishmaniasis. J Venom Anim Toxins Incl Trop Dis. 2011;17:98-102.

25. Forkner CE, Zia LS. Viable Leishmania donovani in nasal and oral secretions of patients with kala-azar and the bearing of this finding on the transmission of the disease. J Exp Med. 1934;59:491-9.

26. Galaï Y, Chabchoub N, Ben-Abid M, Ben-Abda I, Ben-Alaya-Bouafif N, Amri F, et al. Diagnosis of Mediterranean visceral leishmaniasis by detection of Leishmania antibodies and Leishmania DNA in oral fluid samples collected using an Oracol device. J Clin Microbiol. 2011;49:3150-3.
27. Lee YH, Wong DT. Saliva: an emerging biofluid for early detection of diseases. Am J Dent. 2009:22:241-8.

28. Navazesh M. Methods for collecting saliva. Ann NY Acad Sci. 1993;694:72-7.

29. Spanakos G, Piperaki ET, Menounos PG, Tegos N, Flemetakis A, Vakalis NC. Detection and species identification of Old World Leishmania in clinical samples using a PCR-based method. Trans R Soc Trop Med Hyg. 2007:102:46-53.

30. Kent RJ, Norris DE. Identification of mammalian blood meals in mosquitoes by a multiplexed polymerase chain reaction targeting cytochrome $\mathrm{B}$. Am J Trop Med Hyg. 2005;73:336-42.

31. Orsini M, Canela JR, Disch J, Maciel F, Greco D, Toledo Jr A, et al. High frequency of asymptomatic Leishmania spp. infection among HIVinfected patients living in endemic areas for visceral leishmaniasis in Brazil. Trans R Soc Trop Med Hyg. 2012;106(5):283-8. doi:10.1016/j.trstmh.2012.01.008.

32. Sriworarat C, Phumee A, Mungthin M, Leelayoova S, Siriyasatien P. Development of loop-mediated isothermal amplification (LAMP) for simple detection of Leishmania infection. Parasites Vectors. 2015;8:591. doi:10.1186/s13071-015-1202-x.

\section{Submit your next manuscript to BioMed Central and we will help you at every step:}

- We accept pre-submission inquiries

- Our selector tool helps you to find the most relevant journal

- We provide round the clock customer support

- Convenient online submission

- Thorough peer review

- Inclusion in PubMed and all major indexing services

- Maximum visibility for your research

Submit your manuscript at www.biomedcentral.com/submit
) Biomed Central 